\title{
Firm's Engagement in Corporate Social Responsibilities in Nigeria
}

\author{
A. C. Onuorah ${ }^{1} \&$ B. A. Ozurumba ${ }^{2}$ \\ ${ }^{1}$ Department of Accounting, Banking and Finance, Faculty of Management Sciences, Delta State University, Abraka, \\ Nigeria \\ ${ }^{2}$ Department of Financial Management Technology, School of Management Technology, Federal University of \\ Technology Owerri, Owerri, Nigeria \\ Correspondence: A. C. Onuorah, Ph.D, Department of Accounting, Banking and Finance, Faculty of Management \\ Sciences, Delta State University, Abraka, Asaba Campus, Delta State, Nigeria.
}

Received: September 26, 2018

Accepted: October 24, 2018

Online Published: October 29, 2018

doi:10.5430/jms.v9n4p37

URL: https://doi.org/10.5430/jms.v9n4p37

\begin{abstract}
This study examined firms engagement in corporate social responsibilities in Nigeria using secondary data derived from the audited annual reports of the five (5) selected listed Oil and Gas Companies in Nigeria from 2008 - 2018. The study proxied firm's involvement by Firm Age (FMA), Employee Turnover (EPT), Customers Satisfaction (CSF) and Reputation (RPT) as the independent variables, while Responsibility of firms in Nigeria was proxied by CSR as the dependent variable. The study applied GRETL software, and used Ordinary Least Square (OLS) for the estimation of the result. The results revealed that the independent variables: EPT, CSF and RPT have positive significant impact on CSR while FMA shows a negative impact. The coefficient of R-squared which is 0.935067 shows that all the independent variables have $94 \%$ positive impact on CSR while the coefficient of Adjusted R-squared, 0.931820 suggests that $93 \%$ of all independent variables could be explained by the changes in CSR. The study concludes that firm's age is not a strong and powerful measure of CSR as it does not play a significant role in determining the CSR of oil and gas sector in Nigeria. Thus, it was recommended that the management of the selected oil and gas sector should maintain quality assets that are durable. This is necessitated by the potential of the organizations that have such assets to invest more substantial funds towards Corporate Social Responsibility.
\end{abstract}

Keywords: responsibility of firms, oil and gas sector, employee turnover, firms engagement

\section{Introduction}

Over the years, there has been a growing public awareness of the involvement of firms in modern day society and as a result, firms and Corporate Social Responsibilities (CSR) have received much scholarly attention, trying to know if profit maximization is the only concern of firms? Does it have the potency to satisfy both the yearnings of the activist corporation, society and other stakeholders as well? Do other environmental and social concerns play a role as well? Does firm's engagement in CSR activities lead to improved financial performances per say, what are the antecedents of CSR that drives corporations to engage in CSR activities? Can firms benefit by engaging in corporate social responsibilities? Several scholars for decades have investigated CSR and its relationship with the performance of firms to give answer and solution to the above questions (Margolis, Elfenbein\& Walsh, 2011). Despite the fact that answers given are mixed, the line drawn appears to imply that there is a positive relationship between CSR and the performance of firms (Afonso, Fernandes\& Monte, 2012). However, purported benefits of CSR are numerous and include those beyond the "pure" financial, from maintaining the license to operate, to risk reduction, to efficiency gains, and to tax advantages (Bode, Singh \& Rogan, 2015). However, despite the extensive research done on the foregoing questions, its results are still contradictory and ambiguous. In a bid to forestall the further occurrence of this issues brought by these Corporations, modern day businesses have focused attention on being at least socially responsible to its environment where it operates through the rendering of some social and humanitarian services. This approach is based on the guesses that businesses do not exist in a social vacuum, but are part of the society which creates and support them. This connotes that businesses need healthy and steady interaction with the business environment in order for them to acquire enhanced reputation (goodwill) and at the same time achieve their predetermined missions, visions, goals, and objectives while the society in turn gains from the society project executed by the firm. Apparently, the survival, profitability, enhanced reputation, coupled with wealth accumulation of a business is dependent to a great extent on a healthy and friendly environment. 
Businesses continually face pressures from different stakeholders such as customers, community, investors, activist organization and other stakeholders. Employees' pressure to recognize certain employee's rights in the workplace, consumer pressures for the business to withhold price increase and to produce safe products, community and environmental pressures that the business operation does not threaten the safety of the local community has increase sporadically over the years (Marano\&Kostova, 2016). It is therefore paramount for all and sundry to realize that the public outcry for perceived social responsibility will not disappear if firm fail to respond to the challenges these had posed to the society. This statement is further buttressed by WinstonChurchi when he says that "we make a living by what we get, but we make a life by what we give".

CSR is a natural task of every firm to sum for the impact of its activities on the social, economic and environmental aspects of its surrounding and to ensure that this impact results to consistent benefits and absence of harm to all groups of concerned stakeholders (Bruns, 2017). On the other hand, Basil (2014) maintains that the concept of CSR has been nationalized to denote that firms are required to fill the link in numerous social delivers where the government has often failed the citizens reason being that after all the corporations make their money from the patronage of citizens.

\section{Review of Related Literature}

According to the Business for Social Responsibility, CSR can be defined as the achievement of success of a firm in a manner that respect communities, the natural surrounding or the environments, the people and honours ethical values. In this regard, CSR is seen as broad set of practices, programmes and policies that are incorporated into the supply chain of business, business operations and the decision making process in every part of the company and whenever the company does businesses that are supported and rewarded by top management. It also includes responsibility for current and past action and also future impacts.In addition, CSR is about how a business entity gives back to its stakeholders in a sustainable and acceptable manner.

The World Business Councilor sustainable development defines CSR as "the continuing steadfastness of firms to donate to maintained economic growth and development, working with workers (employees), employee's families, local communities and the society to improve the quality of life in ways that are both good for business and development". In a particular society, Banks cannot jettison the environment, community and major coalition members within which they interact. This is owing to the fact that the main thrust for their existence - the accumulation of wealth is only achievable through the existence of their society which constitutes their market. Aguinis (2011) added that the interest group includes but not limited to workers, consumers, and indigenous groups all with a legitimate right to demand socially responsible and right corporate behavior. The stakeholders comprise all members of the society which contribute to or are encumbered by the firm's activities. Thus, it is therefore concerned with treating all stakeholders of the company in an ethical and responsible manner.This implies handling all stakeholders in a manner considered satisfactory in developed nations. Stakeholders are largely grouped into external and internal stakeholders. External stakeholders comprise of customers, government, investors, potential investors, creditors amongst others while internal stakeholders include workers (employees) and management while the. It is striking to note that, the general thrust of CSR is to create better living for the people while maintaining and the profit motive of the firm.

It is in the interest of all stakeholders that all CSR activities enable the firm to stay focused on its mission through proper utilization of its resources in the attainment of its strategic objectives. Harjoto\&Laksmana (2016) submitted that CSR should be strategic no doubt. The study adopts the definition suggested by Bruns (2017) owing to the fact that the definition is all-encompassing, hence, chosen as a guide to this study.

\subsection{Historical Background of CSR in Nigeria}

The historical background of CSR practices in Nigeria could be traced back to the CSR practices in the Oil and Gas Multinational. This CSR activity in this sector is majorly centered on alleviating the effects of exploration activities on the host environment. In addition, in Nigeria, the concept of CSR has been nationalized to denote that firms are required to fill the link in numerous social delivers. Where government have often failed the citizens the thinking being that after all the corporations make their money from the patronage of citizens in addition, the federal government of Nigeria decided to establish the federal environmental protection Agency (FEPA) as stipulated in Decree 58 of 1988 to protect the potential dangers that industrial activities may pose to the environment and the society at large (Basil, 2014). Consequently, the companies provide pipe-borne water, hospitals, schools, scholarships many but few to mention. However, most often these initiatives are ad-hoc and not always sustained. 


\subsubsection{Strategic Roles of CSR}

Corporate social responsibility actions have been meant to comprise corporate social using environmentally friendly technologies achieving degree of ecological routine via the act of recycling and pollution abutment. In the same vein, in most cases efforts of companies to attract employees thereby adopting CSR strategy defeats the original intention of such social obligation, thus, disparity does sometimes exist between the goal of firms and the original intention of CSR when companies dedicate some portion of its assets to community economic development, employment of disabled persons and the mobilization of staff for community services as well as subsidizing costs of operations by offering affordable services to their host community, these are strategic roles of corporate social responsibilities.

\subsubsection{Engagement of Business in the Community}

It has been observed that apart from being profitable, obeying law and being ethical, a company may create positive impact in the community in which it operates by giving basically in two ways (Carrol, 2014):

1. Donating the time and talents of its managers and employees, and

2. Making financial contributions towards the development of the community

The first category is often seen in a wide variety of voluntary activities undertaken by the company staff for the improvement of the living standards in the community while the second has to do with financial budget devoted to the development of the community in a discretionary manner.

Robert Cushman, the President of Norton Company in Worcester, Massachusetts pointed out that "business does not operate in vacuum, but is a social institution interacting with other social institutions: what business does affect its community and in turn, the people's goodwill and trust are essential for business to fulfill its primary role, which is to provide goods and services". Therefore business must, not only for a healthier society but also for its own well-being, be willing to give the same serious consideration on human needs that it gives to its own needs for production and profits.

The following are some of the reasons why business should get involved in community development.

1. Business people are efficient problem solvers - business has the capability.

2. Employees may gain satisfaction and improved morale from engagement in community services.

3. A positive image in the community facilitates hiring.

4. Often companies gain prestige and greater acceptance in a community when it gets actively involved.

5. Social responsibilities in business is alternative to government regulation.

6. Business helps itself by supporting those institutions that are essential to the continuation of business.

It can be concluded from the foregoing that it is good business in itself for business to get engaged in community development. The objectives of making profits by business and at the same time addressing social concerns are therefore not mutually exclusive. There is a general expectation that business has responsibility to build relationship with the community and at the same time be sensitive to its impacts on the community. Reasons why some businesses run into trouble waters with their communities is the lack of this sensitivity. If communities have positive perception about the business and in practical term feel they are beneficiaries of business development in their area, it would be foolhardy for such community to antagonize the business.

\subsubsection{Community Projects}

In an ideal situation where government takes responsibility of providing basic necessities of life for its citizens, the issue of what projects business can undertake for the benefits of the community becomes very simple. But in Nigeria where the government is finding it difficult to satisfy the many expectations of its citizens, businesses are faced with myriad of problems ranging from providing the enabling environment for their operations in the form of infrastructures, security, to fulfilling publicly perceived corporate social responsibility which include what government would normally provide for the people. Consequently, since the impact of the government of Nigeria is not adequately felt in the oil and gas rich communities, the people's attention turns to the oil and gas operators who are drilling oil in their land and water for the provision of the basic needs of life. In other words, the people regard the oil and gas companies as the government they see since they cannot see the one in Abuja, or the State Capital; the Local Government is still struggling with the issue of autonomy. Afterall, the government owns about $60 \%$ of the interests in the oil and gas industry, they reason. This is the dilemma of the oil and gas operating companies in Nigeria as far as corporate social responsibility is concerned (Isung, 2017). 


\subsubsection{Strategic Nature of Business Engagement in Community Development}

As contained in Isung (2017), business engagement in community development should be planned and executed in a way that best fits the business objectives. Engagement in community development is a long term and sustainable goal because the business is not in a hurry to move out of the community: it has come to stay and must be seen to be interested in the affairs of the community. As strategic issue, community development engagement should be brought into sharper alignment with the business efforts, implying that business should get involved in activities that have direct bearing on its overall success.

Elkington (2010) recommend that corporate donations should be done intelligently in the following ways:

1. Align your gifts with your product and goals

2. Choose the right organizational structure for your needs

3. Pick a manager to handle donations

4. Treat grant seekers like customers

5. Set a long term budget for donations

6. Do not run your contributions programme as a public relations exercise

7. Take a chance on an unconventional cause

For Troy (2012) corporate donations should be tailored to meet the bottom line in the following ways:

1. Determine the level of exposure you want for your contributions programme

2. Examine the placement of the contributions programme within your company. Does it report to the logical area to fulfill corporate objectives?

3. Integrate the public affairs, community relations, corporate marketing, and communications goals of your company with your donations programme

4. Make donations work for your company. Determine the public relations value of each potential grant

5. Develop a strategic list of questions to ask each grantee. Make sure the grantee fulfills your requirements.

6. Use executives-on-loan, donated equipment, and marketing-gift programmes to enhance your employee relations and procurement programmes.

\subsection{Theoretical Review}

\subsubsection{Agency Theory (1970)}

The Agency Theory is pointed at the agency relationship, in which one party (the principal) assigns work to another party (the agent). In a business, the principals are considered to be the shareholders, which are the owners of the firm. The managers of companies are considered to be the agents, which are supposed to act in accordance with the principals' (shareholders') goals of wealth maximization. The agency theory is concerned with the fact that agents may behave and act in accordance with their own personal goals rather than with those of the principal. Jensen (1986) posits that owing the division of ownership from management, conflict of interest may arise "since the root opportunistic behaviour is considered to be located in the problems that this particular theory raises."

Firms should only use resources and engage in activities to increase profits while operating within the boundaries of law and regulation. While many studies have continued on this reasoning and investigated CSR as a threat that raises potential conflicts of interest, other agency studies viewed CSR as beneficial to financial and non-financial performance. Either way, agency theory seems to provide an explanation of why firms engage in CSR activities, while others do not.

\subsubsection{Slack Resource Theory (1999)}

Slack Resource theory (SRT) is developed based on the observation that a firm is only able to carry out its activities as a result of the resources available at the disposal of the firm which is normally set aside to the predefined activities. The resources the company needs to adapt to any changes is said to be slack in nature which is often regarded as free resources or available resources used to achieve the firm-specific goals. It is however believed that some of the actions of the firm towards CSR are aimed at developing and increasing the Bank's competitive advantage through image, reputation, long-term cost savings and segmentation (Shehu\& Farouk, 2013). 
The various theories relating to CSR investment and its determining factors reviewed above are very important in determining the reasons why various firm chooses to involve themselves in CSR. Legitimacy theory argues that besides different stakeholder groups, a firm also hold responsibilities to society as a whole, and sinceSectors want to hold their license-to-operate it must show to society that it is working within the boundary of their individual groups.

It is argued that legitimacy, urgency, and power are three attributes that determine stakeholder salience and thus determine which stakeholders are more important to the firm on a given point in time. Agency theory is concerned with the fact that agents may behave and act in accordance with their own personal goals rather than with those of the principal. According to agency theory, CSR is a potential concept that raises a conflict of interest between principals and agents. These perspectives should however not be seen as competing perspectives, but rather as different ways of explaining why corporations involves in CSR actions while others do not. The theoretical perspective that guided the current study is linked to the fact that firms that undertake CSR have public approval than those without it and are deemed to be socially and environmentally responsible to the environment in which the firm is situated.

\subsection{Empirical Review}

Ebiringa, Yadirichukwu, and Chigbu (2013) examined the relationship between firm size and profitability of CSR of some selected oil and gas sectors in Nigeria using secondary data obtained from the audited annual reports and accounts of the selected firms. The result showed a negative relationship between firm size and CSR. However, the result also revealed a positive relationship between profitability and CSR of the selected firms in Nigeria

Afonso, Fernandes, and Monte (2012) examined the relationship between social performance and economic performance of top Portuguese Companies, by using Spearman coefficient, to study the hypothesis of relation between the CSR Index and economic performance variables. The study used 19 Portuguese top firms, quoted in the Euronext Lisbon stock exchange, belonging to PSI 20 Index, considering a review period of five years, from 2005 to 2009. To measure the economic and financial performance, three accounting based measures were used: ROE, ROA and ROS. A clusters analysis was applied to group companies by their social performance and to compare and correlate their economic performance, defined clusters was named in accordance with the social performance of the companies that composed each one (Cluster 1-CSR Medium, Cluster 2- CSR 2High, Cluster 3- CSR Low). Results indicate that companies that had a better social performance are not the ones who had a better economic performance, and suggest that the middle path companies that had a CSR medium and better economic and financial performance in two of the three economic and financial measures of performance should provide a better relationship between CSR and performance as a means for economic growth and development. The positive and significant correlations found, in the group of medium CSR companies, between CSR Index and ROA suggests that social performance may have positive influence on sales, perhaps because consumers are more predisposed to buy goods and services from CSR companies. The total negative correlation between CSR Index and ROE, in the Low CSR companies, that had the better result in ROE and the worst in ROA, it may also indicate that a focus in results to shareholders, neglecting social performance, may have a negative impact in other dimensions, like sales.

Marano\&Kostovo (2016) examined Corporate Social Responsibility, Financial Performance, and Market Performance of consumer goods companies listed on the Indonesian Stock Exchange during the period 2007-2010. The analysis is completed by interviewing consumers, investors, and stock analysts from financial institution in Surabaya, Indonesia. The results of the study show that corporate social responsibility leads to increase in financial performance, but have no significant effect to market performance.

In another research carried out by Carmen-Pilar, Rosa and Lisa (2011) which is aimed at analyzing the effect exerted by CSR on short-term and long-term corporate financial performance of European companies listed in the Stoxx Europe 600 index and Stoxx Europe Sustainability index from 2007 to 2010. Results revealed that the implementation of a CSR strategy, the level of economic development of the country and Bank size determine the ROE of the Bank. The CSP variable is positively and significantly related to the ROE of companies. Thus, companies with more socially responsible activities improve the shareholders' return by realizing higher CFP. Thus, firms in more developed countries obtain significantly better financial performance than other companies situated in less developed countries. In contrast, there was a negative and significant relation between firm's volume of total assets and ROE which could be due to larger firms having a more complex organizational structure that is more formal and centralized than those of smaller firms. The results for ROA showed that the estimators obtained using the different models also presented differences in terms of size and level of significance, as was the case for the ROE specification. The study found a positive and significant relationship between the ROA variable and CSP and the classification of the country in which the company's headquarters were situated, while the relationship between ROA 
and Firm size was negatively significant. The results showed a positive and significant relationship between CSR, CSP and the level of development of the country where their headquarters were located.

Bode, Singh \& Rogan (2015) also analyze the determinants of environmental disclosures in Nigeria, using the oil and gas firms as case study. The study variables include firm Size, profit, leverage, and audit firm type and environmental disclosure. Secondary data were genered from annual reports and the data were subsequently analyzed using the Binary regression technique. The findings showed that there was a significant relationship between company size and CSR disclosure.

Ajide and Aderemi (2014) studied corporate social responsibility activity disclosure and its effect on corporate profitability. They made use of annual reports and accounts of 12 selected companies in Nigeria for the year 2012 only. The multiple regression analysis of ordinary least square (OLS) was adopted for the study. Their findings revealed that firm size and CSR disclosure score have a positive relationship with firm's profitability, while owner's equity has a negative association with firm's profitability. The implication is that when firms show greater dedication to impact and improve people's lives, these in return are capable of improving firm's profitability.

\section{Methodology}

The population of this study consists of twelve (12) oil and gas industry. However, the sample size consists of five (5) oil and gas industries. The selected sample size includes Forte Oil Plc, Mobil Oil Nigeria Plc, Seplat Petroleum Development Company, Total Nigeria Plc, Oando Plc. The choice of the selected firms is based on the availability of data. The non-probability sampling techniques was used, it includes a variety of techniques among which are convenient, purposive or judgmental, quota, panel and multi-stage sampling technique. The study employs data from secondary source only. The data, which are quantitative in nature, have been extracted from the audited annual reports of the five (5) selected listed Oil and Gas firms in Nigeria from 2008 - 2018. The statistical technique of data analysis adopted in this study is the Ordinary Least Square (OLS) method via Gretl. This study is in line with the works of Ajide and Aderemi (2014), Bode, Singh \& Rogan (2015) and Marano\&Kostovo (2016) in their study of firms CRS and performance.

\subsection{Model Specification}

To coddle in empirical analysis of firm's engagement in corporate CSR in Nigeria, CSR was used as the endogenous variable while Firm Age (FMA), Employee Turnover (EPT), Customers Satisfaction (CSF) and Reputation (RPT) were used as the exogenosus variables.

Mathematically, we present the model as:

$\mathrm{CSR}=\mathrm{F}(\mathrm{FMA}, \mathrm{EPT}, \mathrm{CSF}, \mathrm{RPT})$

In explicit form, the model is specified as:

$$
\mathrm{CSR}=\mathrm{b}_{0}+\mathrm{b}_{1} \mathrm{FMA}+\mathrm{b}_{2} \mathrm{EPT}+\mathrm{b}_{3} \mathrm{CSF}+\mathrm{b}_{4} \mathrm{RPT}+\mathrm{E}_{\mathrm{t}}
$$

In long transformation at time period, the model is given as:

$$
\text { LnCSR }=b_{0}+b_{1} \text { LnFMA }_{t}+b_{2} \text { LnEPT }_{t}+b_{3} \text { LnCSF }_{t}+b_{4} \text { LnRPT }_{t}+E_{t}
$$

Where:CSR is Corporate Social Responsibility, FMA is the Firm Age, EPT is the Employee Turnover, CSF is the Customers Satisfaction, RPT is the Reputation, $t=$ stochastic variable or error term, $b_{0}=$ constant term, $b_{1}, b_{2}, b_{3}$ and $\mathrm{b}_{4}$ are parameters to be estimated.

\subsection{Apriori Expectation}

In expectation of what the result of the analysis, we suppose the variables to be either positive or negative yield in value and thus presented as $b_{1}$ FMA, $b_{2}$ EPT, $b_{3}$ CSF and $b_{4}$ RPT $>0$. This implies that the independent variables under study will all have a positive relationship to firms.

\subsection{Decision Rule}

Accept the Null Hypotheses (Ho) if the Probability value (P-value) of the t-statistics is greater than the P-value tabulated at 5\% (i.e. p-value calc> 0.05) level of significance otherwise reject $\mathrm{H} 0$ if the probability value is less than 0.05 .

Note that the p-vale (probability value) is also known as the observed or exact level of the significance or exact probability of committing type 1 error. More technically, the p-value is the lowest significance level at which a null hypothesis can be rejected. Thus, the p-value is at $0.05 \%$. 


\section{Testing of Hypotheses and Results}

Pooled OLS, using 85 observations, included 10 cross-sectional units; Time-series length: minimum 2, maximum 5; Dependent variable: $1 \_C S R$

\begin{tabular}{lllll}
\hline & Coefficient & Std. Error & t-ratio & $p$-value \\
\hline Const & -0.0548856 & 0.117463 & -0.4673 & 0.64159 \\
\hline 1_FMA & 0.971664 & 0.0301466 & 32.2314 & $<0.00001$ \\
\hline 1_EPT & 0.0107863 & 0.0246215 & 0.4381 & 0.66250 \\
\hline 1_CSF & 0.0186037 & 0.0186811 & 0.9959 & 0.32232 \\
\hline RPT & 0.0827411 & 0.163161 & 0.5071 & 0.61347 \\
\hline
\end{tabular}

\begin{tabular}{llll}
\hline Mean dependent var & 3.411908 & S.D. dependent var & 0.903246 \\
\hline Sum squared resid & 4.449990 & S.E. of regression & 0.235849 \\
\hline R-squared & 0.935067 & Adjusted R-squared & 0.931820 \\
\hline F(4, 80) & 288.0081 & P-value(F) & $1.21 \mathrm{e}-46$ \\
\hline Log-likelihood & 4.754576 & Akaike criterion & 0.490848 \\
\hline Schwarz criterion & 12.70410 & Hannan-Quinn & 5.403362 \\
\hline Rho & 0.050761 & Durbin-Watson & 1.789030 \\
\hline
\end{tabular}

White's test for heteroskedasticity

- Null hypothesis: heteroskedasticity not present

- Test statistic: $\mathrm{LM}=6.60895$

with $\mathrm{p}$-value $=\mathrm{P}($ Chi-square $(14)>6.60895)=0.948738$

White's test for heteroskedasticity

- Null hypothesis: heteroskedasticity not present

- Test statistic: $\mathrm{LM}=6.60895$

with $\mathrm{p}$-value $=\mathrm{P}($ Chi-square $(14)>6.60895)=0.948738$

Variance Inflation Factors

Minimum possible value $=1.0$

Values > 10.0 may indicate a collinearity problem

\begin{tabular}{ll}
\hline 1_FMA & 1.138 \\
\hline 1_EPT & 1.168 \\
\hline 1_CSF & 1.240 \\
\hline RPT & 1.034 \\
\hline
\end{tabular}

$\operatorname{VIF}(j)=1 /\left(1-R(j)^{\wedge} 2\right)$, where $R(j)$ is the multiple correlation coefficientbetween variable $j$ and the other independent variables.

Properties of matrix X'X:

- $\quad$ norm $=1814.6597$

- $\quad$ Determinant $=2.0472505 \mathrm{e}+008$

- $\quad$ Reciprocal condition number $=0.0010315218$ 
Fixed effects estimatorallows for differing intercepts by cross-sectional unitslope standard errors in parentheses, p-values in brackets

\begin{tabular}{llll}
\hline const: & -0.35848 & $(0.38457)$ & {$[0.35442]$} \\
\hline l_FMA: & 1.0451 & $(0.10628)$ & {$[0.00000]$} \\
\hline l_EPT: & 0.03535 & $(0.030274)$ & {$[0.24685]$} \\
\hline l_CSF: & 0.043526 & $(0.025861)$ & {$[0.09675]$} \\
\hline RPT: & 0.20536 & $(0.20007)$ & {$[0.30818]$} \\
\hline
\end{tabular}

10 group means were subtracted from the data, Residual variance: $3.45473 /(85-14)=0.0486582$

Joint significance of differing group means:

$\mathrm{F}(9,71)=2.27268$ with p-value 0.0266721

(A low p-value counts against the null hypothesis that the pooled OLS modelis adequate, in favor of the fixed effects alternative.)

Means of pooled OLS residuals for cross-sectional units:

\begin{tabular}{ll}
\hline unit 1: & 0.079616 \\
\hline unit 2: & -0.053044 \\
\hline unit 3: & -0.020618 \\
\hline unit 4: & -0.012638 \\
\hline unit 5: & 0.07452 \\
\hline unit 6: & -0.28529 \\
\hline unit 7: & 0.027681 \\
\hline unit 8: & 0.058889 \\
\hline unit 9: & 0.10365 \\
\hline unit 10: & 0.064059 \\
\hline
\end{tabular}

Breusch-Pagan test statistic:

$\mathrm{LM}=2.2815$ with $\mathrm{p}$-value $=\operatorname{prob}($ chi-square $(1)>2.2815)=0.130925$

(A low p-value counts against the null hypothesis that the pooled OLS modelis adequate, in favor of the random effects alternative.)

Variance estimators:

- $\quad$ between $=0.0212613$

- $\quad$ within $=0.0486582$

Panel is unbalanced: theta varies across units

Random effects estimatorallows for a unit-specific component to the error term(standard errors in parentheses, p-values in brackets)

\begin{tabular}{llll}
\hline const & -0.12654 & $(0.18185)$ & {$[0.48853]$} \\
\hline 1_FMA & 0.98792 & $(0.047144)$ & {$[0.00000]$} \\
\hline 1_EPT & 0.022489 & $(0.026021)$ & {$[0.39003]$} \\
\hline 1_CSF & 0.028215 & $(0.021405)$ & {$[0.19121]$} \\
\hline RPT & 0.11126 & $(0.17482)$ & {$[0.52632]$} \\
\hline
\end{tabular}

Hausman test statistic:

$\mathrm{H}=1.9038$ with $\mathrm{p}$-value $=$ prob $($ chi-square $(4)>1.9038)=0.753447$ 
(A low p-value counts against the null hypothesis that the random effectsmodel is consistent, in favor of the fixed effects model.)

Source: Result extracted from GRETL output (2018)

Random-effects (GLS), using 88 observations

Included 10 cross-sectional units

Time-series length: minimum 7, maximum 10

Dependent variable: 1_CSR

\begin{tabular}{lllll}
\hline & Coefficient & Std. Error & t-ratio & $p$-value \\
\hline Const & 0.00455328 & 0.00569539 & 0.7995 & 0.42630 \\
\hline 1_FMA & 1.00076 & 0.00142289 & 703.3294 & $<0.00001$ \\
\hline 1_EPT & $-1.18509 \mathrm{e}-05$ & 0.000296523 & -0.0400 & 0.96822 \\
\hline 1_CSF & 0.000661583 & 0.000511322 & 1.2939 & 0.19930 \\
\hline RPT & -0.00557746 & 0.00445315 & -1.2525 & 0.21391 \\
\hline
\end{tabular}

\begin{tabular}{lcll}
\hline Mean dependent var & 3.621260 & S.D. dependent var & 0.955842 \\
\hline Sum squared resid & 0.006933 & S.E. of regression & 0.009085 \\
\hline Log-likelihood & 290.8793 & Akaike criterion & -571.7585 \\
\hline Schwarz criterion & -559.3718 & Hannan-Quinn & -566.7682 \\
\hline
\end{tabular}

- 'Within' variance $=1.40035 \mathrm{e}-005$

- $\quad$ 'Between' variance $=5.46668 \mathrm{e}-005$

Breusch-Pagan test

- Null hypothesis: Variance of the unit-specific error $=0$

- $\quad$ Asymptotic test statistic: Chi-square(1) $=141.656$

with $\mathrm{p}$-value $=1.15639 \mathrm{e}-032$

Hausman test

- Null hypothesis: GLS estimates are consistent

- $\quad$ Asymptotic test statistic: Chi-square(4) $=8.83159$

with $\mathrm{p}$-value $=0.0654495$

\subsection{Discussion of Results}

The analysis was tested using ordinary least square test and the result revealed a positive relationship between each independent variables. The result revealed that most of the independent variables have significant impact on CSR of the oil and gas sector in Nigeria because their p-values are all greater than 5\% significant level except the p-value of FMA which is less than 5\% significant level and it is not significantly related to oil and gas sector in Nigeria.

The coefficient of $\mathrm{R}^{2}$ also shows direct relationship as the value of $\mathrm{R}^{2}$ is 0.9351 (93.51\%).

The adjusted $\mathrm{R}^{2} 0.9318$ revealed that $93 \%$ of the independent variables could explain fitness of the model to the dependent variable while the remaining $7 \%$ could not be explained due to financial errors.

\section{Conclusion and Recommendation}

The study sought to examine firm's engagement in corporate social responsibility in Nigeria. To comply with the objective of this research, the study is primarily based on quantitative research method, which obtained data from Oil and Gas Sectors. The study found a negative insignificant association between the firm's age and corporate social responsibility in the Oil and Gas sectors. Thus, it therefore concluded that firm's age is not a strong and powerful 
measure of CSR as it does not play a significant role in determining the CSR of oil and gas sectors in Nigeria. It was recommended that the management of the selected oil and gas industry should maintain quality assets that are durable. This is necessitated by the potential of the organizations that have such assets to invest more substantial funds towards in order to achieve more.

\section{References}

Afonso, S. C., Fernandes, P. O., \& Monte, A. P. (2012). CSR of top Portuguese companies: relation between social performance and economic performance. World Academy of Science, Engineering and Technology, 66.

Aguinis, H. (2011). Organizational responsibility: doing good and doing well. Handbook of Industrial and Organizational Psychology, 3(1), 855-879. https://doi.org/10.1037/12171-024

Ajide, F. M., \& Aderemi A. A. (2014). The effects of corporate social responsibility activity disclosure on corporate profitability: Empirical Evidence from Nigeria Commercial Banks. Journal of Economics and Finance, 2(6), 17-25.

Basil, U. O. (2014, December). Effect of corporate social responsibilities of companies in Ebonyi State. Global Advanced Research Journal of Management and Business Studies, 3(12), 560-569. Retrieved from http://garj.org/garjmbs/index

Bode, C., Singh, J., \& Rogan, M. (2015). Corporate social initiatives and employee retention in the oil and gas sector. Organization Science, 26(6), 1702-1720. https://doi.org/10.1287/orsc.2015.1006

Bruns, A. S. (2017). Corporate social responsibility of firms: empirical evidence from the Netherlands. Unpublished Seminar Paper, University of Twente.

Carmen - Pilar, M. B., Rosa, R. M., \& Lisa, G. J. D. (2011). Do the best European socially responsible companies perform better financially?. Unpublished project, University of Barcelona.

Carol, A. B. (2014). The pyramid of corporate social responsibility: toward the moral management of organizational stakeholders. Business Horizons.

Ebiringa, O. T., Yadirichukwu, E., Chigbu, E. E., \& Obi, J. O. (2013). The effect of firm's age and profitability on corporate social disclosure: The Nigerian Oil and gas in Focus. British Journal of Economics, Management \& Trade, 3(4), 563-574. https://doi.org/10.9734/BJEMT/2013/5147

Elkington, J. (2010). Ideas: Beyond the triple bottom line. Retrieved 13 October, 2017, from http://www.johnelkington.com/activities/ideas.asp

Harjoto, M., \& Laksmana, I. (2016). The Impact of Corporate Social Responsibility on Risk Taking and Firm Value. Journal of Business Ethics, 1-21.

Isung, L. (2017). Corporate Social Responsibility Practices in Nigeria: case of upstream oil and gas companies and their communities in the Niger Delta. Lagos, Talent Publishers.

Jensen, M. (1989). Agency cost of free cash flows, corporate finance and takeovers. American Economic Review, 76(13), 323-329.

Marano, V., \& Kostova, T. (2016). Unpacking the institutional complexity in adoption of CSR practices in multinational enterprises. Journal of Management Studies, 53(1), 8-54. https://doi.org/10.1111/joms.12124

Margolis, J. D., Elfenbein, H. A., \& Walsh, J. P. (2011). Does it pay to be good and does it matter? A meta-analysis of the relationship between corporate social and financial performance. Working paper.

Shehu, U. H., \& Farouk, M. A. (2013).Corporate social responsibilities in the Nigerian companies. International Journal of Economics, Business and Finance, 1(10), 342-351.

Troy, K. (2012). Studying and addressing community needs: corporate case book. New York: the conference board. 